\title{
Counseling Service Management for Students Caracter Building in Facing The World of Work (Case Study in State Polytechnic of Balikpapan)
}

\author{
Patria Rahmawaty ${ }^{1^{*}}$ \\ ${ }^{I}$ Department of Mechanical Engineering, State Polytechnic of Balikpapan \\ "patria_psy@yahoo.com
}

\begin{abstract}
Counseling is one of educational services for the provision of guidance and counseling for students to form the character that ready to work. The purpose of research is to determine the strategy, forms of cooperation, programs used, the results that obtained and an inhibiting and supporting factors of guidance and counseling services. This research used a qualitative approach with case study method, and the method of data collection using observation, interviews and documentation study. The findings of this research include strategies used in guidance and counseling services that incorporate the budget in budget implementation checklists, discussion with the director, research and comparative studies, guidance personnel must be expert in their section. The form of cooperation involves internal and external institutions. The program that used is service of individual counseling, character building and ethics of the profession. The result is students get an overview of the world of work so that many graduates are absorbed by the world of work. Supporting factors that support director, character building materials, and professional ethics, while the inhibiting factor is funds, counselor manpower which less competent, lack of material resources about counseling. The inference is the implementation of guidance counseling at the State Polytechnic of Balikpapan less than the maximum. The recommendations is the head of counseling must be competent, support from the director of real programs, socialization the importance of guidance and counseling for students.
\end{abstract}

Keywords: management services, counseling, character, student and world of work

\section{Introduction}

Education means process to help individuals form a quality personality, guidance and counseling activities the one that holds that role. Guidance and counseling services at the State Polytechnic of Balikpapan as a vocational college graduates who scored a ready to work is expected to shape the character of students in accordance with the needs of the working world.

In addition State Polytechnic of Balikpapan has had counseling services since the establishment of a few years ago and the only vocational colleges that have a guidance and counseling services in Balikpapan. Service counseling conducted in various universities using different methods, adapted to the culture or the vision contained in the mission of the organization. The goal for human resources that their generations have a different characteristic with graduates from other universities. Therefore, programming, strategy, and the proper support in the 
activities of guidance and counseling is needed.

The planning of guidance and counseling program starts from the assessment activities that include the assessment of the environment and the assessment of the needs or problems of learners that can support them to realize the behavior that has competence. Where such competencies include basic service components, responsive service components, individual planning components, and system support components (management).

In carrying out guidance and counseling program requires appropriate service strategy, to in conducting guidance and counseling activities can be evaluated. Further details are in Figure 1.

\section{Methodology}

This research uses a qualitative approach, whereas the method is descriptive (case study). This research was conducted at State Polytechnic of Balikpapan. To collect data, this research used observation, interview and documentation techniques.

\section{Results and Discussion}

\subsection{Results}

Below are the results obtained through interviews to several interviewees at State Polytechnic of Balikpapan. 


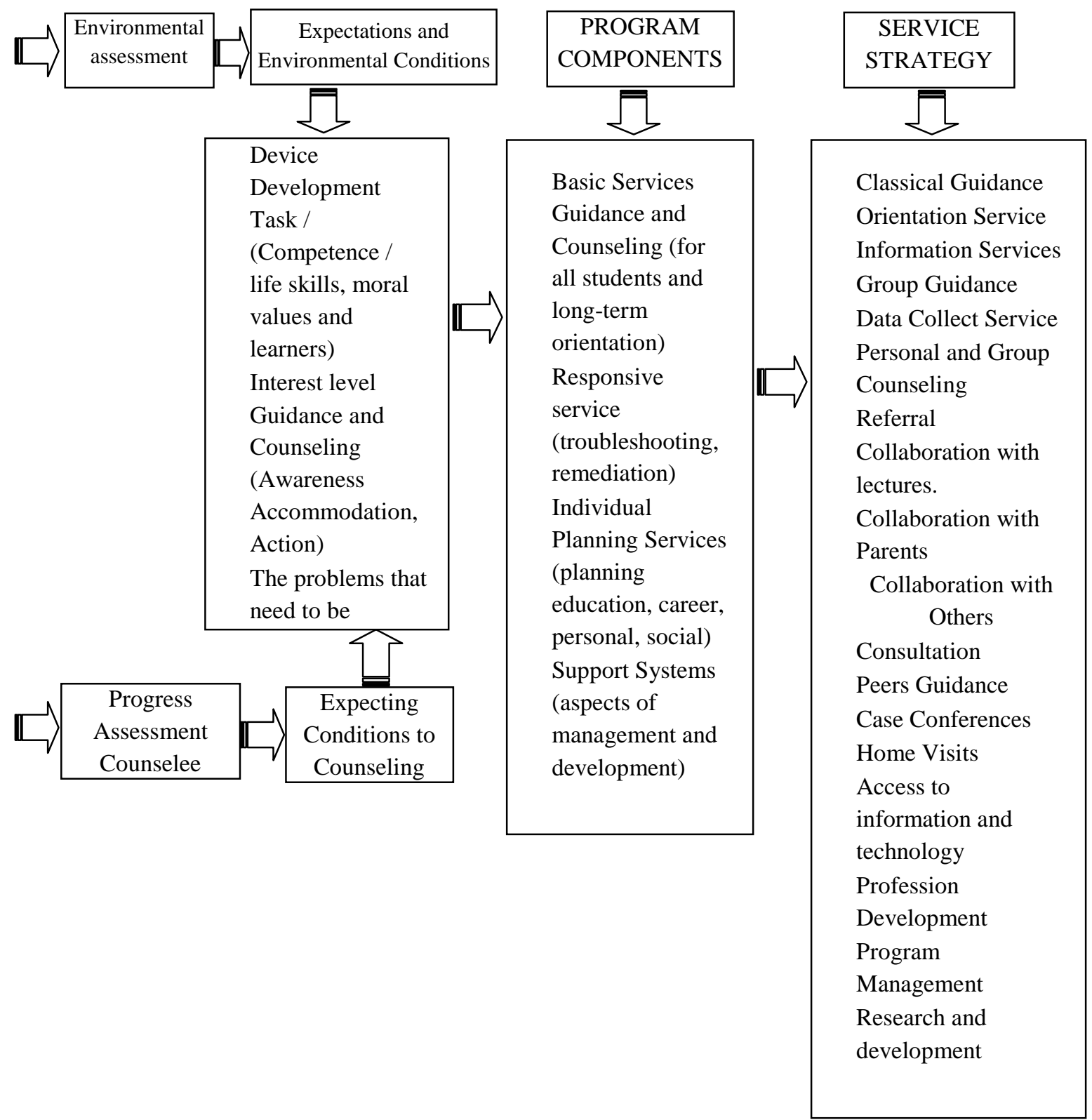

Figure 1. Whole Guidance and Counseling Framework

- Head of Electrical Engineering

Opinion: Providing material character building is not optimal, the counseling had only overcome personal problems of students.

- Head of Culinary

Opinion: Programs are less involved in the preparation of guidance and counseling programs, character building gained through professional ethics

- Head of Mechanical Engineering

Opinion: Programs are only involved to the handling of personal problems of students, whereas for the character building majors are less involved.

Strategy Recommendation: Need consistency in the delivery of the material 
character building, physical development, and giving guidance of competent personnel.

3) Counseling Program

- Head of Guidance and Counseling.

Opinion: The given program is a service of individuals / groups, motivation to learn, self-development and character building. The formation of the character to the world of work through professional ethics

Strategy Recommendation: There are no special programs in addition to the professional ethics of character building, but the counseling services provided during this limited personal counseling.

- 26 students of mechanical engineering ( $4^{\text {th }}$ semester).

Opinion: Service counseling has been known since the orientation, but the character building and handling problem of students are given by professional ethics.

- 14 students of civil engineering $\left(4^{\text {th }}\right.$ semester).

Opinion: Establishment of characters ready to work given through professional ethics, whereas counseling services that unknown in detail.

- 17 students of electronics engineering ( $4^{\text {th }}$ semester).

Opinion: Counseling service prefers leads to completion of a personal problem and not character building

- $\quad 13$ students of culinary ( $4^{\text {th }}$ semester)
Opinion: Counseling was limited to solve personal problems, while the character building is done through professional ethics before On the Job Training.

4) Result obtained from the counseling

- $\quad$ Vice Director III

Opinion: Expect through professional ethics can gain an overview of the world of work.

\section{- Head Counseling}

Opinion: It Submission of professional ethics does not include the formation of character building but helpful enough many graduates to go into large companies.

5) Supporting and Inhibiting Factors

- Head Counseling

Opinion: One of supporting factors is support from director in the implementation of the program. The problem is financial, incompetent counselee, and problem committees in guidance.

$\begin{array}{ccc}\text { Strategy } & \text { Recommendation: } & \text { Always } \\ \text { evaluate, } & \text { service } & \text { program }\end{array}$
individual/groups, as well as specific programs, though not done specifically.

\subsection{Discussion}

The discussion of this strategy contains about preparations, the steps are prepared, and the efforts made to achieve the objectives of the activity. 
1. Strategies in Guidance Counseling Service Management Implementation to building the character of students in entering the world of work.

- Strategies and steps used.

Strategies undertaken by State Polytechnic of Balikpapan in preparing guidance and counseling services are based on a framework of guidance counseling.Planning of the activities undertaken include vision - mission and purpose.Describe the needs of students to guidance counseling services, to formulate the basic concept of the importance of counseling in whole student program that is included on the impact of technological developments in the learning process,social and cultural issues in society, lifestyle and preparation for entering the world of work both in expertise,knowledge, as well as mental attitude in this case the characters needed in the industrialized world.

- Strategies to solve the problem of lack of funds is any program that arranged in writing on the part of planners proposed to be included in the Budget Implementation List (DIPA).

- The efforts to achieve the objectives of the activity are to complete counseling facilities in order to carry out the activities, as well as placing competent counseling officers.

2. Cooperation between the Head of Guidance and Counseling, the Head of Department and Director of the State Polytechnic Balikpapan.

Cooperation carried out by guidance and counseling services in State Polytechnic of Balikpapan against the Director and head of the Department of Mechanical Engineering Equipment, Civil Engineering, and Electronics Engineering and culinary is a reasonable support to the activity. Based on the data obtained above will require the involvement of the department in implementing the program guidance and counseling services with each department can assist in character building for students before entering the world of work. Besides the cooperation with external parties such as private agencies specifically as implementing activities that have been arranged to conduct its activities and government agencies that have a connection with the program have been compiled. The purpose is to broaden the knowledge of students, provide an objective assessment of the status of the student until become graduates who fulfill the requirements of the industrial world.

3. The program used in counseling at State Polytechnic of Balikpapan 
Head of Guidance and Counseling in compiling and sharing program based on input from the Director of State Polytechnic of Balikpapan and Vice Director III, which write down by action plans.In arrange the action plan should be described so that the structure of the program content can be seen.

In determining planning guidance and counseling program, need to pay attention to things like:

- The method used in guidance and counseling services

- The perfect time for the provision of guidance and counseling services, character building.

- The type of program guidance and counseling services should be determined first. (General or special)

During this time the programs running on guidance and counseling services in the development of student character at State Polytechnic of Balikpapan is a personal and group counseling, character building, and professional ethics.

4. Results have been obtained after carrying out management of guidance and counseling services

Implementation of guidance and counseling services that have been performed by State Polytechnic of Balikpapan are enough to help students before entering the world of work.The existence of individual counseling services that address issues of motivation to learn so they remain consistent in finishing their studies.Professional ethics given material to help them get an idea of the world of work. Besides already many graduates of State Polytechnic of Balikpapan working at large companies and earn high salaries.

5. Supporting and inhibiting factors in implementing service management counseling

Factors supporting the implementation of guidance and counseling in order to run properly, including:

- Full support of the Director of the State Polytechnic of Balikpapan on guidance and counseling services about character building of students.

- Head of Guidance and Counseling is given the opportunity to conduct a comparative study at State Polytechnic of Bandung as reference material.This step is taken to update the knowledge and skills possessed.

- Can be planning its own program without anyone intervening.

- To evaluate the activities carried out independently to seek feedback on the activities undertaken. 
- The existence of material professional ethics as a way of character building for students in the program before entering the world of work given by each department can help students to get a picture / description of the world of work that must be faced.

While the inhibiting factors in carrying out the management of guidance and counseling services to character building for students in entering the world of work, which are:

- Limited financial support as operational activities until the earlier activities should consider how much operational funds should be spent.

- Lack of supporting infrastructure related to guidance and counseling services.

- Lack of continuous cooperation of each department in preparing a program on character building for students before entering the world of work. The cooperation between the counseling more dominant handling personal problems.

- Counseling officers' majority did not come from disciplines that should (Bachelor Psychology or Bachelor of Counseling Psychology).

- Evaluation is still generally not prepared on the activities undertaken.

\section{Conclusions}

From the discussion above, the conclusion is the strategy that used mainly in the implementation of management guidance and counseling services at State Polytechnic of Balikpapan is proposing the financial of budget implementation, provision of infrastructure / facilities and human resources in accordance with his expertise in implementing guidance and counseling services. The cooperation is good enough despite the absence of direct cooperation between the director, vice director III, government institutions and the private sector. While the programs used in guidance and counseling services are individual and group counseling, character building, and professional ethics. The results obtained with the guidance and counseling services are work opportunities for graduates and students can entering the world of work easier. Whereas the supporting factors include the support of the Director, research and professional development, professional ethics materials for students and inhibiting factors include the financial, background of the counseling officers.

\section{Suggestions}


Based on the findings during the research, there are some recommendations that can be delivered for the implementation of service management counseling for character building of students in the world of work, which are:

\section{Researcher}

Not easy to find vocational colleges who use the services of counseling in helping students to build their character in preparation for entering the world of work, so the researchers need a more careful and detailed in understanding what issues are an obstacle to draft guidance counseling as appropriate and necessary for student and also can see the profile of other universities that has been carrying out this service function more effectively.

\section{Student}

They need to understand that the importance of a strong and positive character in an attempt to enter the world of work in order to compete with graduates from other universities.

\section{Head Counseling}

The availability of competent counseling officer that have a background in counseling to be able to put together a program that takes the student in forming their character.

4. The Director of the State Polytechnic of Balikpapan

To incorporate the budget for the operational activities of counseling in the Budget Implementation List and give a chance to the counseling officer to developed themselves according to their expertise.

\section{All Readers}

The importance of character building for students are it can help to entering the world of works and get success after they graduate.

\section{References}

Direktorat Jendral Peningkatan Mutu Pendidikan dan Tenaga Kependidikan Departemen Pendidikan Nasional (2007). Rambu-Rambu Penyelenggaraan Bimbingan Konseling Dalam Jalur Pendidikan Formal. Jakart $a$.

Ernest Dale and L.C Michelon. (1986).Modern Management Methodes. Jakarta: Andalas Putra.

Fenti Himawati. (2011). Bimbingan Konseling. Jakarta: PT. Raja Grafindo Persada.

Jayaningrat. (2009). Implementasi Pelayanan Bimbingan Konseling di Sekolah Menengah Kejuruan Negeri I Lubuk Linggau. Hal.3.

Jhon N Rosyandi. (1986). Metode-metode Manajemen Modern. Jakarta: Andalas.

Peraturan Menteri Pendidikan Nasional Nomor. 41 tahun 2011 tentang Pendirian, Organisasi, dan Tata Kerja Politeknik Negeri Balikpapan. Jakarta: Kementrian Pendidikan Nasional.

Richardus Eko Indrajid dan Djokopranoto. (2006).Manajemen Perguruan Tinggi Modern. Yogyakarta: CV.Andi Offset.

Wanda Chrisiana. (2005). Upaya Penerapan Pendidikan Karakter Bagi Mahasiswa (Studi Kasusdi Jurusan Teknik UK Perta. Jurnal Pendidikan dan Kebudayaan. Vol 5.Surabaya. 